\title{
Notes on Some Turkic Vowel Developments
}

\author{
Julian Rentzsch \\ Mainz
}

\begin{abstract}
This contribution deals with four types of vowel developments found in Turkic languages. Two of these, i-umlaut and $u$-umlaut, are regressive vowel assimilations, the other two-vowel raising and vowel lowering - originate in a reduction in terms of quantity. In order to get a rough idea of the distribution of the phenomena under discussion, modern Standard Uyghur, a language in which these developments are especially common, is taken as a starting point. Lexemes in which one or more of these changes occur are compared with the cognates in other modern and historical Turkic languages. It turns out that while most of the vowel developments considered here have gained a certain dissemination accross the Turkic world in individual lexical items, the instability in the vowel system is especially striking in the Uyghur area.
\end{abstract}

Keywords: Turkic languages, phonology, lexis, etymology, sound harmony, umlaut, vowel raising, vowel lowering.

\section{Progressive and regressive vowel assimilations}

In Turkic languages, sound assimilations usually operate progressively (i.e. the preceding syllable influences the following with respect to 
certain sound features.) Sound assimilations typical for Turkic languages are palatal harmony and labial harmony. Palatal harmony renders an opposition front vs. back [ \pm front]. In Uyghur for example, there is a plural suffix with a front (palatal) variant -ler and a back (velar) variant -lar. The appropriate variant is selected according to the stem. Hence, the plural of oy 'house' is oyler, the plural of oy 'thought' is oylar. Labial harmony renders an opposition round vs. unround [ \pm round]. In Kirghiz, the plural suffix has the unround variants - Ler and $-L a r$ and the round variants -Lör and -Lor. The plural of ay 'month' is aylar, the plural of oy 'thought' is oylor. Although palatal and labial harmony are often collectively referred to as "vowel harmony", palatal harmony affects consonants as well. In Uyghur, the dative of $\ddot{y}$ 'house' is oyge; the dative of oy 'thought' is oyra. The configuration of palatal and especially labial harmony differs considerably between the various Turkic languages. What is common to all varieties of Turkic is that these sound harmony processes operate progressively.

However, in some Turkic varieties there are also regressive vowel assimilations. ${ }^{2}$ These are especially striking in the Southeastern branch of Turkic and are often referred to as umlaut. Two different types of umlaut phenomena, as well as two unrelated but equally striking types of vowel reduction will be the topic of this contribution.

1 The factors determining the choice of the suffix variants are quite intricate: On the one hand, there are cases where not the stem vowel, but the stem as a whole seems to carry the sound harmony information, as in iš 'work', which is [+back] although the stem vowel / $\mathrm{i} /$ is ambiguous in this respect (hence suffixed forms like išlar, išqa, et cetera). On the other hand, there are cases where the stem vowel determines the suffix vowel even if the stem ends in a consonant that unambiguously carries the opposite sound harmony feature: Thus, xelq 'people' takes front vowel suffixes although the consonant auslaut is back (xelqler, xelqte). This results in suffix variants that are hybrid with respect to sound harmony (in other words, in which there is no intra-syllabic sound harmony), as the dative suffix variant -qe in xelqqe.

2 In some Turkic languages, there are also regressive consonant assimilations, as Yakut orommut 'our beds' from oron 'bed', or spoken Uyghur kiuller 'days' from kiin 'day'. Consonant assimilations will not be dealt with in this article. 


\section{I-umlaut}

I-umlaut is a vowel assimilation phenomenon typical for Uyghur. It affects the low unrounded vowels /a/ and /e/ in initial open syllables. In this position, /a/ is raised and fronted to a closed /e/ if a primary $/ \mathrm{i} /{ }^{\beta}$ occurs in the subsequent syllable. For example, the Turkic word sarï 'yellow' is represented as seriq in Uyghur (UTIL 3: 650), T yarim 'half' as Uyg yerrim (UTIL 6: 694), T yanï 'new' as Uyg yèi (UTIL 6: 723-724) and T yašil 'green' as Uyg yěšl (UTIL 6: 709). /e/ in open initial syllables is raised to /é/ as well, but unlike /a/, there need not be a primary /i/ in the following syllable. Hence, Uyghur has kerek 'necessary' from T kergek (with an intermediate form kerek, Clauson 1972: 742) and keler 'will come' from the verb stem kel- 'to come'.

The Uyghur converb form yetip may be derived from either yat'to lie' and yet- 'to reach', as the converb suffix contains a primary /i/. On the other hand, Uyghur has kelidu 'comes' (with the shift /e/ $>/$ è/) but qalidu 'remains' (without the shift $/ \mathrm{a} />/ \dot{\mathrm{e}} /$ ), as the $/ \mathrm{i} /$ of the aspect suffix $i d u$ is a secondary development from /e/ and /a/ (*keledur, * qaladur). ${ }^{4}$

I-umlaut is fully productive in that it is not restricted to lexical units, but also occurs under suffixation if the necessary conditions for umlauting are fulfilled. Loans do not undergo umlauting consistently; hence Uyghur has héli 'a moment ago, in a moment' (UTIL 5: 581) from Arabic hăli 'present' with umlaut but hali 'its state' (Uyg hal 'state' from Arabic $h \bar{a} l$ ) without (UTIL 5: 454-457). An epenthetic /i/ may trigger umlaut, as in méyiz 'kernel, marrow' < *mayiz < $\mathrm{P}$ mag $z$.

3 There is no systematic contrast between /i/ and /i/ in modern Uyghur. The phoneme resulting from the merger of Turkic /i/ and /i/ is represented by /i/ in this contribution.

4 The conditions for this process are described exhaustively by Hahn (1991: 5152 ), while most of the other sources are less exact. - There is a considerable dialectal variation within the Uyghur area with respect to the question to which degree umlaut is employed. If we compare the data presented on the southern dialects of Uyghur by Jarring (1933: 90-94) with the situation in the modern standard language, it becomes clear that the process is much more advanced in the standard language. This may be both due to the situation in the dialects the Uyghur standard language is based on, and to a diachronic progression. 
The Uyghur i-umlaut resembles the i-umlaut of Germanic and Eastern Middle Iranian. It might have been triggered by an IndoEuropean substratum.

Similar phenomena are also reported for the Uzbek dialects around Namangan, see Wurm 1959: 499 and Rešetov and Šåabdurahmånov 1978: 38. Sporadically, it occurs in other varieties of Turkic as well. The Turkish lexemes yessil 'green' and yeni 'new' display the same vowel development, ${ }^{5}$ while the neighboring Azerbaidjani has the original yašil for the former (but also yeni for the latter). Standard Uzbek has sekin 'slowly' (ÖTIL 2: 33-34; likewise Uyghur sékin, UTIL 3: 665) from Arabic sākin 'quiet'. Kazakh bäri 'all', originally bar 'existing' with the possessive suffix, also displays fronting of /a/ under the influence of a subsequent $/ \mathrm{i} /$. Erratic forms like thesealthough probably resulting from the same process-are purely lexical, while in Uyghur the process is productive (i.e. the mechanism remains active under speech). This is even true within the lexical stem. For example, the intensive derivation of yěsil, which is formed by a reduplication of the first syllable, is yapyešil 'very green' (UTIL 6: 405) in Uyghur, that is, under the process of derivation the original form yašil is taken as the basis. Conversely, the corresponding Turkish form is yemyeşil, with the innovative form as the basis for derivation. ${ }^{6}$

Although i-umlaut usually is restricted to open syllables, there are also instances of umlaut in closed syllables: yessi 'flat' (UTIL 6: 708) from T yasï (Clauson 1972: 973-974). One may speculate that the umlauting occurred prior to the lengthening ("gemination") of $/ \mathrm{s} / \mathrm{.}^{7}$ Nadžip (1968: 797) records this word as yése, without consonant lengthening, but with an additional vowel lowering in the second syllable (see below).

5 To which the initial /y-/ may have contributed.

6 Note also the diverging final consonant of the reduplication syllable.

7 Likewise in the word yessimuq 'lentil'. The original Turkic form was probably yasmuq, as most modern Turkic languages preserve a similar form, cf. Uzb yasmiq (ÖTIL 2: 488), Tur yasmık. Clauson (1972: 975) records an Old Uyghur form yasimuq, which I would argue to derive from an older form *yasmuq with an epenthetic vowel /i/. The Modern Uyghur form may either directly originate from Old Uyghur yasimuq, or be a contamination from yasmuq with the etymologically related adjective yéssi. 


\section{U-umlaut}

U-umlaut is the labialization of low vowels in initial syllables under the influence of a round vowel in the subsequent syllable, i.e. a partial regressive assimilation that adds the feature [+round] to the vowel. This phenomenon has been noted by Pritsak (1959a: 538) for modern Uyghur, see also Johanson 1998: 93. It is extremely frequent, though not productive, in this language and may affect both words of Turkic origin and loans. There is also a limited set of lexemes in which forms with $\mathfrak{u}$-umlaut have spread beyond the limits of Uyghur.

An example for this is the Turkic word etiik 'boot' (Clauson 1972: 50) which appears in Uyghur as ötuik (UTIL 5: 796), in Ili Salar as ö:tüx (Yakup 2002: 148), in Kirghiz as ötük (Judaxin 1965: 602), in Altay Turkic as ödük (Baskakov and Toščakova 1947: 118), in Qumandï $^{8}$ as ödük or ödek (Baskakov 1972: 238), in Tuba (Baskakov 1966: 141) and Quu as ödük and ödök (Baskakov 1985: 182) and in Xakas as ödlk 'shoe' (Baskakov and Inkižekova-Grekul 1953: 133). On the other hand, Uzbek, the closest relative of Uyghur, has etik (ÖTIL 2: 455) with the frequent delabialization of /U/ in non-initial syllables. The same form is attested for Kazakh (Bektaev 2001: 166), Karakalpak (Baskakov 1967: 903, entry sapogi) and Kumyk (Bammatov 1969: 379). That the / $\ddot{\mathrm{u}} /$ of $\mathrm{T}$ et $\ddot{u} k$ has been delabialized at a very early stage in some Turkic varieties can be seen from the Koman (fourteenth century) form etik (Grønbech 1942: 969). Further forms without umlaut are Tatar itek (TatRS 180), Tuvan idik 'shoe' (Tenišev 1968: 201) and Turkmen $\ddot{a}$ :dik (TDS 824). Siberian variants like ödek and $\ddot{\partial} d \ddot{k} k$ display a vowel lowering in the second syllable (see below).

Another example of a word with spread $\mathrm{u}$-umlaut is Turkic erïk 'stone fruit' (Clauson 1972: 222), which appears in Uyghur as ör ïk 'apricot' (UTIL 5: 807). Uzbek has umlaut as well: orik (ÖTIL 2: 510-511) with later delabialization of the / $\ddot{\mathrm{i}} /$ of the second syllable. The fact that in this lexeme the u-umlaut is quite old is shown by the fact that or rïk <'wrwk> is attested as early as in the Baburname (e.g. 3 r13) which was finished in $1530.9^{9}$ Variants with umlaut are also

8 Qumandi (Kumandin), Tuba (Black Forest Tatar) and Quu (Lebed' Tatar) are northern varieties of Altay Turkic.

9 Thackston transcribes this word as $\ddot{u}$ ritk, which is not at all impossible: After the labial assimilation erïk > örük, /ö/ could have been raised to /ü/, resulting in 
present in Kirghiz örük (Judaxin 1965: 600), Kazakh örik (Bektaev 2001: 374) and Ili Salar öröx (Yakup 2002: 148). ${ }^{10}$ The variant without umlaut, erik, occurs among other things in Koman (Grønbech 1942: 92), Karakalpak (Baskakov 1967: 14, entry abrikos), Kumyk (Bammatov 1969: 376), Karachay-Balkar (Tenišev and Sujunčev 1989: 770, meaning: 'plum') and Turkish (meaning: 'plum').

U-umlaut is less spread in the Turkic word čaruq 'a rough, homemade boot' (Clauson 1972: 428), which appears in Uyghur as čoruq 'sandal' (UTIL 2: 686) and Karachay-Balkar as čruq 'boot' (Tenišev and Sujunčev 1989: 738), the latter with total assimilation, but in Uzbek as čåriq (ÖTIL 2: 379) without umlaut (cf. Tur çarlk).

The Turkic verb egsï- 'to be/become defective/deficient//acking' (Clauson 1972: 117) displays u-umlaut in the Baburname: öksü- 'to

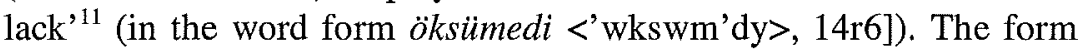
with umlauting survives both in Uyghur (öksï-, UTIL 5: 837) and Uzbek (oksi-, ÖTIL 2: 502).

The Turkic word qamiiš 'reed' (Clauson 1972: 628-629) is qomuš in Uyghur (UTIL 4: 291) and xomus in Yakut (Slepcov 1972: 496) with an intermediate *qamušs ${ }^{22}$, while Babur Turkic has qamǐs <q'myš> (288r7) and Uzbek qamiš (ÖTIL 2: 547).

The Mongolic word serigün 'cool' (Khalkha serï̈n) appears in Yakut as sörïïn (Slepcov 1972: 337) and in Uyghur as sörün (UTIL 3: 605), but in Uzbek as sarin (ÖTIL 2: 23), in Altay Turkic as seriï̈n (Baskakov and Toščakova 1947: 128), in Tuvan as seriin (Tenišev 1968: 374) and in Turkish as serin. Xakas has the variants sörön and siren (Baskakov and Inkižekova-Grekul 1953: 197, 188), i.e. one vari-

a total assimilation of the vowel of the initial syllable to the vowel of the subsequent syllable. However, taking the Uyghur and Uzbek forms into consideration, örik seems the more plausible reading. - The form *iiruik is indirectly attested by Tatar örek (TatRS 740). In Kazan Tatar, /u/ and / /u/ have been lowered to $/ \mathrm{o} /$ and $/ \ddot{\partial} /$, while $/ \mathrm{o} /$ and $/ 0 / \mathrm{h}$ have been raised to $/ \mathrm{u} /$ and $/ \ddot{\mathrm{u}} /$ (Thomsen 1959: 411). It has not yet been completely understood how exactly this development evolved. The orthographical $<\mathrm{e}\rangle$ in the second syllable, by instance, is not the result of a vowel lowering of the type described below, but represents a reduced high front vowel $(</ \mathrm{i} /)$. - The form iurilk is also found in the Uyghur dialects of Southern Xinjiang (Jarring 1964: 328).

10 Russian urjuk 'dried apricot' is probably a loan of the umlauted Turkic form öriik (cf. Vasmer 3: 189, where no etymology is offered for urjuk).

11 Zenker 127 gives meanings like 'to diminish'.

12 Vowel labialized under the influence of $/ \mathrm{m} /$. 
ant with and another without umlaut. The underlying form copied into Turkic from Mongol seems to have been *seriuin.

Besides these very few lexical items, u-umlaut seems to be more or less restricted to Uyghur. Here is a list with examples for $\mathrm{u}$-umlaut in Uyghur which is not paralleled in other Turkic languages, with the corresponding Old Turkic forms. Uzbek as the closest relative of Uyghur is quoted as well.

böšïk 'cradle' (UTIL 1: 515) < T bèšük (Clauson 1972: 380); Uzbek bešik (ÖTIL 1: 108).

tošu- 'to carry' (UTIL 2: 248) < T tašu- (Clauson 1972: 561); Uzbek taši- (ÖTIL 2: 138).

tomur 'vein, artery' (UTIL 2: 285) $<$ tamur $^{13}<\mathrm{T}$ tamür (Clauson 1972: 508); Uzbek tåmir (ÖTIL 2: 200).

tonu- 'to know' (UTIL 2: 291-292) < T tanu-(Clauson 1972: 516); Uzbek tani- (ÖTIL 2: 117-118).

töšïk 'hole' (UTIL 2: 360-361) < tešük (Clauson 1972: 563); Uzbek tešik (ÖTIL 2: 169). ${ }^{14}$

tömür 'iron' (UTIL 2: 367) < temür < T temir (Clauson 1972: 508); Uzbek temir (ÖTIL 2: 158).

xotun 'woman, wife' (UTIL 2: 855-856) < T xatun (copied from Sogdian, Clauson 1972: 602-603); Uzbek xåtin (ÖTIL 2: 334).

qozuq 'peg, stake' (UTIL 4: 248) < qazuq < T qazүuq (Clauson 1972: 682); Uzbek qåziq (ÖTIL 2: 592-593).

qošuq 'spoon' (UTIL 4: 258) < T qašuq (Clauson 1972: 671); Uzbek qåšiq (ÖTIL 2: 607).

qoyun 'melon' (UTIL 4: 265) < T qayun (Clauson 1972: 611); Uzbek qåvun (ÖTIL 2: 591); the Baburname has qavun <q'wwn> (e.g. $5 \mathrm{r} 2)$.

očuq 'open, clear' (UTIL 5: 619-620) < T ačuq (Clauson 1972: 22); Uzbek åčiq (ÖTIL 1: 552).

oruq 'emaciated, skinny' (UTIL 5: 637) < T aruq (Clauson 1972: 214); Uzbek åriq (ÖTIL 1: 542).

13 With labialization of the second vowel triggered by the labial consonant $/ \mathrm{m} /$. The Turkish form of this word, damar, originates from the variant tamar which is also attested in Old Turkic (Clauson 1972: 508).

14 This word survives also in Turkish deşik 'pierced; hole'. 
ozuq 'provisions' (UTIL 5: 645-646) < T azuq (Clauson 1972: 283); Uzbek åziq (ÖTIL 1: 524).

ošuq 'more than' (UTIL 5: 651) < T *ašuq; Uzbek åšiq (ÖTIL 1: $555)$.

yopurmaq 'Blatt' (UTIL 6: 580) < T yapuryaq (Clauson 1972: 879 880); Uzbek yapråq (ÖTIL 2: 484-485) ${ }^{15}$.

yopuq 'cover' (UTIL 6: 583) < *yapuq ${ }^{16}<$ T yapïy (Erdal 1991: 215); Uzbek yåpiq (ÖTIL 1: 260).

yoru- 'to become bright, to shine' (UTIL 6: 591-592) < T yaru(Clauson 1972: 956); Uzbek yåri- (ÖTIL 1: 261).

yoruq 'light, bright' (UTIL 6: 588) < T yaruq (Clauson 1972: 962963, Erdal 1991: 255); Uzbek yåru (ÖTIL 1: 262). In modern Uyghur, there is a contrast between yoruq 'light, bright' (with uumlaut) and yeriq 'gap' (UTIL 6: 693, with i-umlaut). The earliest occurrence of the latter (eleventh century) is in the form yaruq (Erdal 1991: 255). However, the immediate predecessor for the Uyghur form yeriq must have been *yariq with an unrounded vowel in the second syllable. It is not clear why and at which stage this vowel had been delabialized in an environment in which round vowels are usually preserved. One contributing factor might be a late reflex of the vowel length in the Old Turkic verb stem ya:r- 'to split' (Erdal 1991: 255). Note that this stem is preserved in modern Uyghur as yar- (UTIL 6: 438), while the verb stem underlying yoruq is yoru-. The Uzbek form yarruy-with the round vowel (irregularly) preserved and the final consonant voiced - seems to be a Chaghatayism.

yošur- 'to conceal' (UTIL 6: 592) < T yašur- (Clauson 1972: 979); Uzbek yašir- (ÖTIL 2: 491).

Some Arabic and Persian loans undergo this process as well, e.g.

tonur 'tandoor' (UTIL 2: 289) $<\mathrm{P}$ tanür or tandür.

zörür 'necessary' (UTIL 3: 335) < A darürī.

qobul 'acceptance' (UTIL 4: 224) < A qabül.

nomus 'honor' (UTIL 5: 393) < P nāmūs. 
Uyghur hosul 'harvest' (UTIL 5: 546) seems to go back to an intermediate *hasul, although the Arabic model is hăsil (Southern Xinjiang: ha:sill, et cetera, Jarring 1964: 115).

U-umlaut turns out to be most common in Uyghur among all Turkic languages. Almost all Turkic words in which u-umlaut operates display it at least in Uyghur. There are however, erratic word forms with something resembling u-umlaut where there is no parallel in Uyghur, e.g. Tuba sögis 'eight' (Baskakov 1966: 149), the Uyghur cognate being sekkiz. There is no obvious etymological motivation for a word form like sögis (*seküz), as the common Turkic form is sekkiz (Clauson 1972: 823).

The rounding of Common Turkic /a/ to /a/ which is often observed in Uzbek is not related to the regressive labial assimilation process under description here, as it occurs irrespective of the vowel in the subsequent syllable. ${ }^{17}$ Hence, Uzbek has /å/ in $\stackrel{a}{\gamma i z}$ 'mouth' (ÖTIL 1: 561-562) (T ayiz, Uyg èiz) as well as in yåriq 'gap' (ÖTIL 1: 262) (T yaruq, Uyg yeriq) and yåruy 'light' (ÖTIL 1: 262) (T yaruq, Uyg yoruq).

As it becomes obvious from the examples quoted, u-umlaut most frequently occurs in open syllables. Hence, Uyghur has artuq 'excess, more than' (not *ortuq) ${ }^{18}$, tekšür- 'to check' (not *tökšür-) and yastuq 'pillow' (not *yostuq). There are however examples to the contrary, like öksï- 'to lack' from T egsï- (see above) and öcke 'goat' from T ečkï (see below).

\section{Vowel raising in non-initial syllables}

In Uyghur, low vowels in open non-initial and non-final syllables undergo an extreme degree of reduction, resulting in a reduced central high vowel. This phenomenon, which is fully productive, has been labelled raising by Hahn (1991: 52). In written Uyghur, the resulting vowel is indicated by the letter for $<\mathrm{i}>$, e.g. <öylirimizdiki> 'the one being in our houses' instead of *öylerimizdeki. However, this reduced

17 This statement is true both synchronically (where there is rarely a high round vowel in the second syllable in Uzbek) and diachronically.

18 Interestingly, Yakut has precisely the umlauted form orduq (from $\mathrm{T}$ artuq) not permitted in Uyghur (Slepcov 1972: 276). 
vowel has a different phonological status than the primary Uyghur /i/, which corresponds to Common Turkic /i/ and /i/. (E.g., the reduced vowel does not trigger i-umlaut.) Neither the reduced vowel nor the primary /i/ affect the palatal harmony status of the word.

In connected speech, word-final low vowels may be raised as

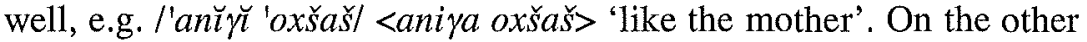
hand, stressed vowels are never raised, for example, <neme qilarini bilmey> 'without knowing what to do' (not *qilirini).

Vowel reduction in Eastern Turki dialects is commented on by Jarring as follows:

"Die reduzierten Vokale sind ein sehr charakteristisches Element im Osttürkischen. Besonders in einem schnell gesprochenen Wortschwall sowie bei Vokalen in schwachtoniger Stellung tritt eine Tendenz zur Vokalreduzierung hervor, die wohl ausserhalb einer Türksprache ohne Gegenstück ist."

(Jarring 1933: 41)

In modern Uyghur, precisely this wortschwall has been taken as the phonetic basis of the standard language.

Reduced vowels in non-initial syllables are common in many Turkic languages. In many cases, the reduced vowels are marked for some phonological oppositions like [ \pm back], [ \pm round], [ \pm high] or all. Uyghur is different in this respect.

All syllables subject to intersyllabic sound harmony must have undergone a previous stage of reduction. In this respect, the Uyghur vowel raising is related to the intersyllabic sound harmony phenomena common to almost all Turkic languages.

\section{Vowel lowering in non-initial syllables}

The vowel phenomena referred to so far are strikingly concentrated on the Uyghur area although they do occasionally occur in other varieties of Turkic as well. The phenomenon to be considered next, by contrast, is much more spread across the Turkic world. In some lexemes, high vowels $(/ \mathrm{i} /, / \mathrm{i} /, / \mathrm{u} /, / \ddot{\mathrm{u}} /)$ in non-initial syllables become lowered. Depending on the labial harmony rules of each language, the lowering 
of the vowel is often accompanied by delabialization of former round vowels.

A well-known example for vowel lowering is the Turkic word kemi 'ship, boat' (Clauson 1972: 721) which survives with a closed vowel in Oghuz: Tur/Azr gemi, Tkm gä:mi (TDS 232), Ili Salar ki:mu (Yakup 2002: 135), but with an open vowel elsewhere: Uyghur has keme 'ship, boat' (UTIL 4: 743) with the vowel modification in the first syllable described above under the heading "I-umlaut", Uzb kema (ÖTIL 1: 378), Kaz keme (Bektaev 2001: 233), Krg keme (Judaxin 1965: 371), Krč keme (Tenišev and Sujunčev 1989: 322), Kumyk geme (Bammatov 1969: 96), Alt keme (Baskakov and Toščakova 1947: 79), Xak kime (Baskakov and Inkižekova-Grekul 1953: 75) and Tuv xeme (Tenišev 1968: 473). The form keme is attested in the Codex Cumanicus (14th century, Grønbech 1942: 137), which proves that the lowered vowel in this word is quite old.

The high vowel of Old Turkic töpü 'hil1, top' (Clauson 1972: 436) has been lowered all across the Turkic world: Uyghur has töpe (UTIL 2: 352), Kazakh töbe (Bektaev 2001: 446), Kirghiz döbö (Judaxin 1965: 198), Altay töbö (Baskakov and Toščakova 1947: 154) and Yakut töbö (Slepcov 1972: 393). The Oghuz forms tepe (Turkish, Azerbaidjani) and depe (Turkmen, TDS 248) as well as Uzbek tepa (ÖTIL 2: 161) have their first vowel delabialized as a result of regressive assimilation.

The Old Turkic word yügün 'bridle' (Clauson 1972: 913) has undergone vowel lowering everywhere, too: ${ }^{19}$ Uyg yïgen (UTIL 6: 678), Uzb yugan (ÖTIL 2: 462), Kaz ž̈̈̈gen (Bektaev 2001: 211), Krg jügön (Judaxin 1965: 272), Alt üygen (Baskakov and Toščakova 1947: 171), Xak čügen (Baskakov and Inkižekova-Grekul 1953: 324), Tuv čügen (Tenišev 1968: 549).

Uyg bèket 'station, stop' (UTIL 1: 533), Uzb bekat 'station, stop, postal station' (ÖTIL 1: 97), Krg beket 'postal station' (Judaxin 1965: 126) and Kaz beket 'station, postal station' (Bektaev 2001: 99) probably developed from Old Turkic beküt, which Clauson (1972: $325)$ registers as a hapax legomenon derived from the verb stem bekii'to be firm'.

19 However, Yakut iuin (Slepcov 1972: 459) seems to point to an underlying *yiigün rather than *yiigen. 
The high vowel of Old Turkic sïnük 'bone' (Clauson 1972: 838839) survives only in Azerbaidjani sümük. It has been lowered elsewhere: Uyghur sönek (UTIL 3: 620), Uzbek songak (ÖTIL 2: 97) and suyak (ÖTIL 2: 90-91), Turkmen (archaic) süyek (TDS 615), Kazakh sïyek (Bektaev 2001: 424). The contracted form söök which occurs in Kirghiz (Judaxin 1965: 659-660) and the Siberian Turkic languages Altay (Baskakov and Toščakova 1947: 131), Tuvan (Tenišev 1968: 386) and Xakas (Baskakov and Inkižekova-Grekul 1953: 196) hints at an older form *söyek with vowel lowering, as *sönük, at least in Kirghiz ${ }^{20}$ and (Southern) Altay $^{21}$, should have developed to * siük (Tuvan and Xakas are less instructive in this respect).

Old Turkic yoyun 'thick' (Clauson 1972: 904) maintains its high vowel only in Oghuz (Tur yoğun, Tkm yoyi:n, TDS 297), while lowering has taken place elsewhere: Uyg yoyan 'huge, massive'

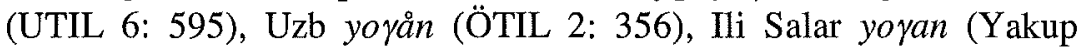
2002: 130), Kaz žuwan (Bektaev 2001: 207). Kirghiz (Judaxin 1965: 261) and Altay (Baskakov and Toščakova 1947: 56) have joon < *yoyan. The Tuvan (Tenišev 1968: 540) and Xakas (Baskakov and Inkižekova-Grekul 1953: 320) form čoon could have developed from either*yoyan or *yoyun.

The Uyghur word čöček 'fairytale' (UTIL 2: 709) is probably related to Old Turkic sürčik (Clauson 1972: 845; however, Clauson is not aware of the connection). The elision of $/ \mathrm{r} /$ is quite common in Uyghur (e.g. in Uyg töt 'four' < T tört), and the initial /s/ has been assimilated to /č/ as in Uyg čač 'hair' < T sač. Wherever *sürčük survives, vowel lowering has occurred: Uzb čopčak ${ }^{22}$ 'riddle, fairytale' (ÖTIL 2: 387, URS 551), Alt čörčök (Baskakov and Toščakova 1947: 181), Qumandï čöry̌ek, čörček, čörčök (Baskakov 1972: 269), Tuba čörčök (Baskakov 1966: 166), Quu čörǰök, čörčŏk, šörǰök, šöršök (Baskakov 1985: 223).

Much less uniform is the picture in the following cases: Old Turkic toyuru 'straight, right' (Clauson 1972: 473) has become torra (with lowering) in Uyghur (UTIL 2: 248-249) but toyri (without

20 Cf. Menges 1959: 442.

21 Cf. Pritsak 1959b: 580.

22 I have no idea about how the /p/ came into being. 
lowering) in Uzbek (ÖTIL 2: 260). The high vowel has been preserved in Turkmen doyrï (TDS 261) and Turkish doğru. Some Kipchak languages have preserved the high vowel as well, as Karakalpak tuwri (Baskakov 1967: 822, entry prjamo) and Tatar turi (TatRS 558), while others have a low vowel, as Kazakh tuwra (Bektaev 2001: 448), Kirghiz tuura (Judaxin 1965: 772-773), Kumyk tuwra (Bammatov 1969: 321) and Karachay-Balkar tuwra (Tenišev and Sujunčev 1989: 657). The split within Kipchak is already present in Koman, which has both the conservative form toyru (Grønbech 1942: 247) and the innovative variant tuwra (Gronbech 1942: 258). The Altay lexeme tuura 'breadth, width' (Baskakov and Toščakova 1947: 159) as well as the Xakas word to rira 'against' (Baskakov and Inkižekova-Grekul 1953: 229) without doubt also stem from the same Old Turkic word.

Old Turkic tolu 'full' (Clauson 1972: 491-492) has correspondences with a low vowel in Uyghur tola "much, very" ${ }^{23}$ (UTIL 2: 273), Uzbek tola 'full' (ÖTIL 2: 246), Kirghiz tolo (Judaxin 1965: 746) and Altay tolo (Baskakov and Toščakova 1947: 152). Most languages preserve the closed vowel: Karachay-Balkar tolu (Tenišev and Sujunčev 1989: 643), Kumyk tolu (Bammatov 1969: 319), Kazakh tolï (Bektaev 2001: 444), Karakalpak tolï (Baskakov 1967: 719, entry polnyj), Tuvan dolu (Tenišev 1968: 170), Turkish dolu, Ili Salar do:li (Yakup 2002: 80).

The Old Turkic word sögüt 'tree' (Clauson 1972: 819) is not very widespread in the modern Turkic languages. It survives with an open vowel in Uyghur söget 'willow' (UTIL 3: 619) and Kirghiz sögöt (Judaxin 1965: 657). Turkish söğüt and Turkmen söwüt (TDS 605) preserve the closed vowel. Xakas sööt (Baskakov and InkižekovaGrekul 1953: 197) could be based both on *sögüt and *söget (cf. Pritsak 1959c: 609). The word does not exist in Uzbek and Kazakh, which use tal instead.

What is yötuil 'cough' (Clauson 1972: 889-890) in Old Turkic has a low vowel in Uyghur yötel (UTIL 6: 638), Uzbek yotal (ÖTIL 1: 355), Kazakh žötel (Bektaev 2001: 207), Kirghiz jötöl (Judaxin 1965: 266) and Yakut sötöl (Slepcov 1972: 337). Altay however, the vowels

23 'Full' in Uyghur is toluq (UTIL 2: 278-279) with another deverbal noun suffix. The equivalent toliq exists in Uzbek, too (ÖTIL 2: 246-247). 
of which often behave similar to Kirghiz, has preserved the high vowel: jödül (Baskakov and Toščakova 1947: 57). The same is true for Tuvan čödül (Tenišev 1968: 542) and Xakas čidrl (Baskakov and Inkižekova-Grekul 1953: 316).

The word for 'brain' is mène in Uyghur (UTIL 5: 279-280) and miya in Uzbek (ÖTIL 1: 468). Almost all other Turkic languages in which this word is disyllabic have a high vowel in the second syllable (e.g. Tur beyin, see Clauson 1972: 348-349 for further examples). The Proto-Turkic form of this word is reconstructed as *beji by Clauson. While both Uyghur and Uzbek have lowered the second vowel, the closed /è/ of the first syllable in Uyghur could possibly be attributed to an i-umlaut (meni $>$ meni) prior to the vowel lowering (the original Turkic closed /è/ is usually not preserved in Uyghur, e.g. T berr- 'to give' > Uyg ber-).

The Turkic word böri 'wolf' (Clauson 1972: 356) displays vowel lowering in Uyghur böre (UTIL 1: 513) and Yakut börö (Slepcov 1972: 78), but maintains the high vowel elsewhere, e.g. Uzb bori (ÖTIL 1: 164), Kaz böri (Bektaev 2001: 108), Krg börü (Judaxin 1965: 153), Alt börü (Baskakov and Toščakova 1947: 34), Tuv börï (Tenišev 1968: 118), Ili Salar bü:ri (Yakup 2002: 65).

Uyghur tillke 'fox' (UTIL 2: 407) corresponds to Old Turkic tilkï (Clauson 1972: 498-499). ${ }^{24}$ Virtually all languages except Uyghur preserve the high vowel: Uzbek has tulki (ÖTIL 2: 222), Kazakh tillki (Bektaev 2001: 452), Kirghiz tülkü (Judaxin 1965: 780), Altay tülkï (Baskakov and Toščakova 1947: 161), Xakas tülgü (Baskakov and Inkižekova-Grekul 1953: 242), Ili Salar tülgü (Yakup 2002: 170) and Azerbaidjani tïlkii. Tuvan dilgi (Tenišev 1968: 162) as well as Turkmen (TDS 649) and Turkish tilki preserve the unround vowel of Old Turkic in the first syllable, but have /i/ in the second syllable due to labial harmony. Only in Qumandï, forms with low vowel (tülge, tülgö, tülke) are recorded besides forms with high vowel (tülgi, tülkii) (Baskakov 1972: 258).

Uyghur has qoza 'lamb' (UTIL 4: 246) for Old Turkic quzi" (Clauson 1972: 681). A first step of vowel lowering is visible in the Ili

24 Labialization of the vowel of the first syllable occurs frequently in this item. Already Babur Turkic (sixteenth century) has tiilkii <twlkw> (71r5-6). (The word tiilkii occurs thrice at this place, the third occurrence is misspelled as tiiklii.) 
Salar form Goza (Yakup 2002: 109), although the process is not yet completed in this language. All other languages preserve the high vowel, as Uzbek qozi (ÖTIL 2: 630), Kazakh qozi (Bektaev 2001: 288), Kirghiz qozu (Judaxin 1965: 392) and Turkish kuzu. The Baburname, incidentally, has qozi <qwzy> (164r12) with a high vowel as well.

In the items mentioned so far, vowel lowering can be observed in at least one language besides Uyghur. However, there are a lot of instances in which this phenomenon is restricted to Uyghur:

burya 'auger, drill, gimlet; wind instrument made from the horn of an animal' (UTIL 1: $494^{25}$ ) < T buryuy (Doerfer 2: 286-288; Clauson 1972: 361). Interestingly in Uzbek, a split has occurred between the regular buryi 'auger, drill, gimlet' (ÖTIL 1: 154; URS 85) with delabialization of $/ \mathrm{u} /$ in the second syllable and bur $\gamma u$ 'pipe, horn' (URS 85); 'ancient wind instrument' (ÖTIL 1: 154) with the labial vowel preserved. The latter form is either an archaism or has been taken into the standard language from a different dialect. The word survives with various meanings in Kaz buryi 'drill' (Bektaev 2001: 114), Krg buryu 'drill' (Judaxin 1965: 160) and Ili Salar bur yu 'ox horn' (Yakup 2002: 65). In Turkish, burgu 'auger, gimlet; corkscrew; screw; peg to tighten a string in stringed instruments; torture screw; kind of trumpet' (Redhouse 201) exists side by side with the etymologically related item boru 'pipe, tube; horn, trumpet' (cf. below, entry mora).

Although Doerfer (2: 288) rejects a connection to Mongolian büriy-e/büriyen 'trumpet, horn' (Lessing 1960: 149) ${ }^{26}$ as "lautlich unmöglich", it is my conviction that the Mongolic item has been copied from Turkic buryu, especially if we take the alternative spelling bürege (Lessing 1960: 148) into consideration. ${ }^{27}$ The

25 I kančiliq néfit, ximiye sana'iti gèologiyilik qidiriš ve šu qatarliq išlarda qėziš,

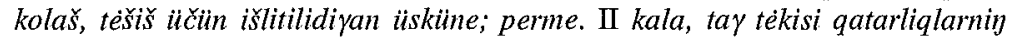

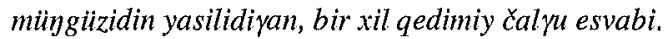

26 Khalkha birree(n) 'trumpet, horn' (Vietze 1988: 67; BAMRS 307), Kalmuck bilree 'Blasinstrument, Trompete' (Ramstedt 1935: 67).

27 The only possible objection against the assumption of a loan of Turkic burry into Mongolian in the form biirege is the change of palatal harmony (back > front). However, variation in palatal harmony (in both directions) is not uncommon even within Turkic; cf. Old Turkic milyizzmiliziz $(<*$ bitinitz, 
Tuvan form büree 'trumpet (musical instrument)' (Pal'mbax 1953: 616, entry truba) is without doubt a loan from Mongolic.

buya 'deer' (UTIL 1: 502-503) < Mongolian buyu; cf. Babur Turkic

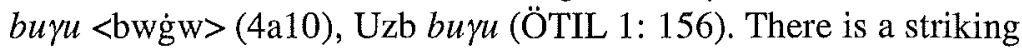

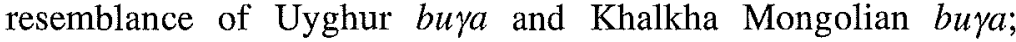
however, the word is certainly not borrowed from Khalkha; rather, the low vowel in Uyghur buya is the result of an internal Turkic development, while the sound written $<a>$ in the second syllable of the Khalkha word reflects an internal Mongolic development $^{28}$ (Posch 1964: 124).

tïge 'millet' (UTIL 2: 399) < T tïgi (Clauson 1972: 478). Does not exist in Uzbek, which uses tariq or sok instead (both teriq and sök exist in Uyghur as well).

čoqqa 'summit, top' (UTIL 2: 688); Uzb čoqqi (ÖTIL 2: 389).

čine 'porcelain bowl' (UTIL 2: 790) < P čiñ 'Chinese, porcelain'; cf. Uzb činni 'porcelain' (ÖTIL 2: 370).

dora 'medicine, remedy' (UTIL 3: 94) < P dārū.

This word is an example of $\mathbf{u}$-umlaut and vowel lowering occurring in one word. It is clear, that the labialization $/ a />/ 0 /$ in the initial syllable must have preceded the lowering $/ \mathrm{u} />/ \mathrm{a} /$ in the second syllable. Uzbek has dåri (ÖTIL 1: 234) with a delabialized high vowel in the second syllable. The Kazakh form däri (Bektaev 2001: 141) obviously results from a fronting (i-umlaut) of /a/ after delabialization of the second vowel (dāru $>$ dari $>$ däri).

döše 'wooden chopping board' (UTIL 3: 129; Nadžip 1968: 447) < M döši 'anvil' (Lessing 1960: 269; cf. Yakup 2005: 448).

qošaq 'folk song' (UTIL 4: 253) < T qošuy (Clauson 1972: 671); Uzb qošiq (ÖTIL 2: 643).

qošna 'neighbour' (UTIL 4: 257) < T qonši (Clauson 1972: 640) with metathesis; Uzb qošni (ÖTIL 2: 644); cf. Tur komşu.

Clauson 1972: 352) 'Horn', Uyghur mïygüz, Kazakh miiyiz, Kirghiz müyüz, Altay miïis vs. Turkish boynuz, Tuvan mïyïs (front > back); Old Turkic bïj 'thousand', Uyghur min (contrary to the first impression, this word is back: e.g. the plural is minlar), Kazakh min, Tuvan mum vs. Kirghiz min, Turkish bin (back > front); Old Turkic yégirmi ' 20 ', Uyghur yigirme, Uzbek yigirma, Turkish yirmi vs. Kazakh žiyïma, Kirghiz jïÿma (front > back).

28 On the other hand, although the sound changes in Turkic and Mongolic have lead to slightly different results in terms of phonetics, we may note a certain similarity in terms of sound development in the Turkic-Mongolic contact area. 
$q \dot{e} z a$ 'horse meat sausage' (UTIL 4: 378) <* qe zi <* qazi< T qazi 'the fat on a horse's belly, a sausage made from such fat' (Clauson 1972: 681); Uzb qazi (ÖTIL 2: 536). ${ }^{29}$ In this word, both i-umlaut and vowel lowering can be observed.

keke 'adze' (UTIL 4: $541^{30}$ ) <*kerke < T kerki (Clauson 1972: 741). This word seems to survive in Uyghur only. ${ }^{31}$

kötek 'stump; tear-off slip, counterfoil' (UTIL 4: 620 ${ }^{32}$ ) $<$ T ketük 'notch, chip' (Clauson 1972: 702). This is a deverbal noun from ket- 'to notch/chip/gash' (Clauson 1972: 700). ketiik has become gedik 'gap; notch' in Turkish, with the usual phonological developments. The Uyghur form kötek displays both u-umlaut (ketük>*kötük) and vowel lowering (*kötük > kötek).

kïlke 'laughter' (UTIL 4: 707-708) < T külgü (Clauson 1972: 718); Uzb kulgi (ÖTIL 1: 404), Kaz külki (Bektaev 2001: 257), Krg külkü (Judaxin 1965: 463), Xak külk (Baskakov and InkižekovaGrekul 1953: 96), Ili Salar külgü (Yakup 2002: 137).

kirpe 'hedgehog' (UTIL 4: 759) < T kirpi (Clauson 1972: 737); Uzb kirpi $^{33}$ (ÖTIL 1: 388; URS 214), Krg kirpi (Judaxin 1965: 389), Kaz kirpi (Bektaev 2001: 259).

mora 'chimney' (UTIL 5: 175). A loan from Persian mōrt 'an earthen pipe joined to an aqueduct; a watercourse, channel, gutter' (Steingass 1892: 1343), which in turn is probably a loan from Turkic bori/boru 'pipe, tube', which is derived from Old Turkic buryu, see above. Steingass transcribes the Persian word as mūrt, but the Tadjik form mōri 'chimney, smoke outlet' (TRS 250) as

29 Clauson (1972: 681) erroneously notes that this word does not survive in the southeastern group of Turkic ("s.i.a.m.1.g. except SE, SW").

30 tiyi destisige ornitilidiyan ‘̌epiš, yonuš qorali.-Nažip (1968: 640) gives the following meanings: I rezec; II 1. kirka; 2. toporik mestnogo izgotovlenija; 3. nož dlja rubki solomy i klevera.

31 Russian kirka 'pick' very much looks like a loan of Turkic kerki (possibly even the variant with lowered vowel). The word must have been quite widespread in pre-modern Turkic and is even recorded in Ottoman dictionaries (Redhouse 641: kerki 'large ax'). However, Vasmer 1: 560-561 mentions Ottoman Turkish kürek 'shovel, paddle' as a possible model for the Russian word.

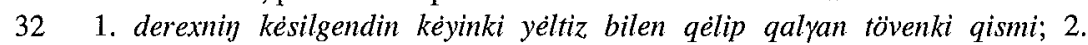
di'ametri čon, tom, qisqaraq yayač; 3. talon ve ispatlami yézip bergende, talon ve ispatniy yezip bergüčide qèlip qalidiyan qismi.

33 According to the Uzbek dictionaries, kirpi is a dialect form, the standard form for 'hedgehog' being tipratikan. 
well as the loaned forms in Turkic bear witness to the $w \bar{a} w-i$ majhul ${ }^{34}$. In Uyghur, the second vowel is lowered. The word exists in Uzbek as mori 'chimney" ${ }^{35}$ (ÖTIL 1: 490) and in Kirghiz as mor 'chimney', southern dialects mooru (Judaxin 1965: 532). For the Uyghur dialects of Southern Xinjiang, Jarring (1964: 198) notes the variants mori and mo:r $\varepsilon$ 'chimney'. The latter form will be commented on below.

here 'bee' (UTIL 5: 498) < T arï, with prothetic /h/; Uzb ari (ÖTIL 1: 53). For unknown reasons, this lexeme has front vowels in Uyghur.

hoyla 'courtyard' (UTIL 5: 551); Uzb håvli 'courtyard' (ÖTIL 2: 702); Tkm hovli (TDS 714); cf. Tur avlu 'courtyard'. The Tadjik form of this item is havli 'courtyard' (TRS 494), written <hwly> in Arabic letters (TRS 646). This lexeme is very interesting in terms of etymology. It is very likely that all the variants noted here (all carrying the same meaning) are derived from one common origin. Jarring (1964: 122) claims that the Eastern Turki word hojli/hojle/hojla originates from an Arabic/Persian word $<$ hwly>. This word is in fact attested in Farsi (Junker and Alavi 1965: 257), Afghan Persian (DRS 310, with a variant havili $<$ hwyly>) and Tajik (TRS 646). Steingass does not mention this word. Arabic has no word $<$ hwly $>$ in a meaning that makes a direct borrowing into Persian probable, but the Persian word could be reasonably related to Arabic haula <hwl> 'around' (Wehr 1985: 309) with Persian $y \bar{a}-y i$ nisbat, originally meaning something like 'surroundings', which could have acquired a more narrow semantics of 'surroundings of a house' > 'courtyard'. However, Redhouse (98, entry avlu) and Zenker (397, entry $h w l w / h w l y)$ claim this word to be of Greek origin, which would relate it to Greek $\alpha v \dot{\nu} \eta$ 'court' (cf. Latin aula, German Aula and

34 I.e. the long vowel phoneme $/ \overline{\mathrm{o}} /$ that has merged with $/ \overline{\mathrm{u}} /$ in the western varieties of Persian.

35 Interestingly, Uzbek has a de-nominal verb morala - 'to peer', 'to peep' (podsmatrivat', podgljadyvat' (čerez čto-l.); vygljadyvat', URS 277; Tosiq, tirqiš, tešsik årqali qaramåq, ÖTIL 1: 490), without doubt derived from mori, with the same vowel lowering as in Uyghur mora. A very similar case of vowel lowering in a derivation is the Ottoman Turkish word borazan 'trumpeter' (Redhouse 190), a de-nominal noun derivation from the word boru already mentioned. 
the English adjective aulic). The latter possibility seems much more plausible to me. In this case, the Greek word $\alpha \dot{\nu} \lambda \dot{\eta}$ would have been borrowed into Turkic in the form *avli. While in Turkish, the word was first accommodated to the rules of palatal harmony ( $>a v l i$ ) and after that to labial harmony (rendering avlu, with the second vowel rounded under the influence of the labial consonant $/ \mathrm{v} /$ ), the word received a prothetic $/ \mathrm{h} /$ in Central Asia. In Uyghur, the $/ \mathrm{i} /$ was lowered to $/ \varepsilon /$ and later adapted to the rules of palatal harmony (all three stages are noted by Jarring 1964). Regarding the question whether the word entered South East Turkic via Persian or was borrowed into Persian from Turkic, I would argue for the latter possibility, as innovative forms with a prothetic $/ \mathrm{h} /$ are typical for Southeastern Turkic, but not so for Persian. The orthography with $\langle\mathrm{h}\rangle$, which usually points to words of Arabic - not Persian or Turkic-origin, could result from an erroneous etymological identification (i.e. a contamination) with Arabic haulia 'around', hawālī 'vicinity', et cetera.

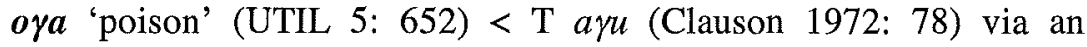
intermediary form *oyu. This is another example of $\mathrm{u}$-umlaut and lowering occurring in one word. This word survives in Uzbek as å $\gamma u$ (ÖTIL 1: 564), in Kirghiz as $u u$ (Judaxin 1965: 809), in Kazakh as $u w$ (Bektaev 2001: 457) and in Xakas (Baskakov and Inkižekova-Grekul 1953: 127), Tuvan (Tenišev 1968: 321) and Quu (Baskakov 1985: 181) as oo. Ili Salar a: $\gamma$ u (Yakup 2002: 34) preserves the Old Turkic state.

öčke 'goat' (UTIL 5: 798) from Old Turkic ečkü (Clauson 1972: 24) also combines u-umlaut and vowel lowering. Umlaut has also occurred in Tuv öškü (Tenišev 1968: 342) and Xak ösk̆ (Baskakov and Inkižekova-Grekul 1953: 137). Most Turkic languages have delabialized the second syllable: Uzb ečki (ÖTIL 2: 456457), Kaz eški (Bektaev 2001: 167), Kkp eški (Baskakov 1967: 345, entry koza), Krg ečki (Judaxin 1965: 969), Kumyk ečki (Bammatov 1969: 380), Krč ečki (Tenišev and Sujunčev 1989: 779), Alt ečki (Baskakov 1964: 248, entry: koza); the Oghuz form kečl (with metathesis) displays the same change. Ili Salar ešgu (Yakup 2002: 90) is again closest to Old Turkic. Also in öcke, the umlauting must have preceded the lowering (ečkü> öčkü>öčke). 
yėza 'village, countryside' (UTIL 6: 700-701 ${ }^{36}$ ) < T yazï (Clauson 1972: 984); Uzb Ø. Cognates are Krg jazi 'broad, wide' (Judaxin 1965: 212) and Xak čazï 'field, steppe' (Baskakov and Inkižekova-Grekul 1953: 306). This lexeme contains i-umlaut and vowel lowering: yazï > yezzi $>$ yeza.

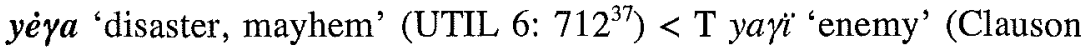
1972: 898). The Uyghur form displays both i-umlaut (yayi > yeji) and vowel lowering $(y \dot{e} \gamma i>y \dot{e} \gamma a)$. Babur Turkic has preserved the original form: $y a y \ddot{i}\langle y$ 'gy> 'foe' (e.g. 218r1). Xak and Tuv čaa 'war' (Baskakov and Inkižekova-Grekul 1953: 304; Tenišev 1968: 503) are contracted from yayi. Uzbek has the Kipchak form yåw 'enemy, desaster' (ÖTIL 1: 252), which is also found in Alt juu 'war, battle' (Baskakov and Toščakova 1947: 58), Tat yaw 'foe' (TatRS 719), Kaz žaw 'foe' (Bektaev 2001: 189), Krč jaw 'foe' (Tenišev and Sujunčev 1989: 235-236) and Krg joo 'foe' (Judaxin 1965: 260). The Kipchak form is attested in modern Uyghur as well: yaw 'foe' (UTIL 6: 521 ${ }^{38}$ ). Here, two etymologically identical forms have assumed different meanings.

Vowel lowering in final syllables is also observed in three Uyghur numerals:

yigirme 'twenty' (UTIL 6: 770) < T yégirmi (Clauson 1972: 915), cf.

Tur yirmi. Corresponding forms with lowered vowels exist in various Turkic languages, e.g. Uzb yigirma (ÖTIL 1: 347), Kaz žiyirma (Bektaev 2001: 200), Kir jiÿirma (Judaxin 1965: 278) and Yak süïrbe (Slepcov 1972: 352).

yette 'seven' (UTIL 6: 537) < T yetti (Clauson 1972: 886); Uzb yetti (ÖTIL 1: 251); cf. Yak sette (Slepcov 1972: 370).

alte 'six' (UTIL 1: 159) < T altï (Clauson 1972: 130); Uzb ålti (ÖTIL

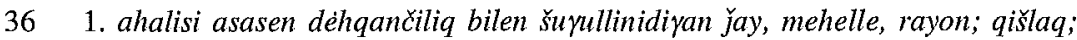
sehra;

2. memlikitimiznì memuriy rayon bölinmmisidiki asasiy qatlam teškiliy orgini. adette nahiye yaki nahiye derijilik organnī bašqurušida bolidu. unin bašqurušida yene kentler bolidu.-Nadžip (1968: 797) gives the meanings derevnja, selo (i.e., 'village').

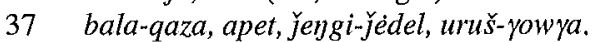

38 uruš, jendiki qarši terep; diišmen, reqib.-Nadžip (1968: 798) mentions only the form yè $\gamma a$ 'bedstvie' ('disaster, affliction'). 
1: 534); cf. Yak alta (Slepcov 1972: 39). The non-harmonic form of this item suggests that it represents a case of recent lowering.

In some Uyghur dialects, vowel lowering seems to be even more widespread than in the standard language. For the dialect of Khotan (Uyg Xoten), forms like könel for Standard Uyghur könül 'heart', biigen instead of SUyg bügün 'today', toxa instead of toxu 'chicken' and oyal in place of oyul 'son' are reported (Sayim 2007: 11). ${ }^{39}$ On the other hand, some dialects have more conservative forms, e.g büri/böri 'wolf' (Jarring 1964: 62, cf. Yakup 2005: 443; SUyg böre), to rrï 'straight' (Jarring 1964: 309) and tǔrru (Yakup 2005: 471; SUyg toyra), tülki 'fox' (Jarring 1964: 318; SUyg tülke), da:ru; do're 'medicine, drug, spice, spices' (Jarring 1964: 81; SUyg dora), qozï 'lamb' (Jarring 1964: 253; SUyg qoza), qošni 'neighbour' (Jarring 1964: 253; SUyg qošna), kerki 'adze' (Jarring 1964: 167; SUyg keke), külgü 'laughter' (Jarring 1964: 179; SUyg külke), kirpi 'hedgehog' (Jarring 1964: 174; SUyg kirpe), morï/mo:re 'chimney' (Jarring 1964: 198; SUyg mora), mini 'brain' (Jarring 1964: 196; SUyg mène), hojli/hojle 'courtyard, yard, house, palace' (Jarring 1964: 122; SUyg

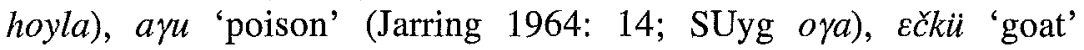
(Jarring 1964: 39; SUyg öčke), jazi/jazil/je:zi 'country, countryside' (Jarring 1964: 151; SUyg yéza) and jayiljił ï 'enemy, rebellious' (Jarring 1964: 152; SUyg yé $\gamma a$ ).

While vowel lowering of the type described above is very common in Uyghur words, there are cases where this sound change occurs in other Turkic languages while it is absent in Uyghur. The Old Turkic word boyuz 'throat' (Clauson 1972: 322) has a high vowel in many Turkic languages, e.g. Tur boğaz 'throat', Kaz buwaz 'pregnancy' (Bektaev 2001: 109). Krg booz 'pregnant' (Judaxin 1965: 144) and Alt boos 'pregnant' (Baskakov and Toščakova 1947: 33) testify to an underlying form *boyaz as well, otherwise these items should appear as *buuz/buus respectively. On the other hand, Uyghur boyuz 'throat, fodder' (UTIL 1: 468) and Uzbek boyiz 'throat' (ÖTIL 1: 167-168) preserve the original structure of the word. Uzbek standardized as yése in Soviet Uyghur (Nadžip 1968: 797), reflecting a slightly different dialectal basis. 


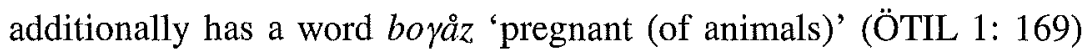
of the same Turkic origin, but possibly borrowed from Kipchak.

The Turkic word yan $\ddot{i}$ 'new' displays vowel lowering in a number of Kipchak languages, e.g. Tatar yana and Kazakh žana, and also in Yakut saya, but not Uyghur, where it is yeji. ${ }^{40}$

Another word for 'courtyard' (besides Uzb håvli/Uyg hoyla, see above) in South East Turkic is Uzbek qora (ÖTIL 2: 639)/Uyg qoru (UTIL 4: 242). ${ }^{41}$ The exact etymological affiliation of this word is not clear. One feels, of course, tempted to relate it to T qori $\gamma$ 'enclosure' (Clauson 1972: 652; cf. Tur koru 'grove'), which is a nominal derivation from the verb qori- 'to protect' (Uzb qori-, Uyg qoru-), but this word survives regularly as Uyg qoruq (UTIL 4: 243, entry qoruq II) and Uzb qoriq (ÖTIL 2: 640) with meanings like 'field; shelter, cover, et cetera'. Both form and meaning of qora/qoru however, make a relation to the verb qori- obvious. We could speculate that qoralqoru are the remnants of an otherwise unattested Turkic noun *qori 'shelter, protection', of which qori- is a zero-derivation (as in $k \ddot{o ̈ c}$ 'migration' > köč- 'to migrate', tüz 'level' > tüz- 'to level' and yar 'cleft' > yar - 'to cleave'). In this case, Uzb qora would display vowel lowering in the second syllable, while Uyg qoru would represent a more conservative stage.

In Yakut, vowel lowering occurs in a couple of inflectional morphemes, e.g. the 3 rd person singular possessive suffix in $-(t) E$ ( T $(s) i)$ and the 3rd person singular preterite in $-D E(T-D I)$.

\section{Origin and development of umlaut and vowel lowering Umlaut}

In his chapter on modern Uyghur in the first volume of the Fundamenta, Pritsak (1959: 538) explains umlaut as an influence of the stressed second syllable on the unstressed first syllable:

"Das ursprüngliche, betonte enge $i / i$ der zweiten Silbe verändert

40 In spoken Uyghur however, also in the spoken standard language, the /i/ of yejzi can be realized as a mid central vowel/a/.

41 The words are not totally synonymous, qoralqoru being also used for a pen, i.e. an enclosure for animals. 
das breite $a / \ddot{a}$ der unbetonten offenen Silbe [...] in e. [...] Das ursprüngliche betonte enge $u / \ddot{i}$ der zweiten Silbe verändert das breite a/ä der ersten offenen Silbe [...] in $o / \ddot{o} . "$

However, we need not take it for granted that the first syllable was unstressed. While Turkic stress in general is only insufficiently explored, almost nothing is known about stress on the historical stages of Turkic (cf. Räsänen 1949: 32-41). Umlaut does not require unstressed initial syllables. The Germanic umlaut, for instance, affects the stressed syllable (German Buch-'Bücher; Norwegian bok-bøker). If Pritsak's assumption on the former stress configuration in Uyghur is true, the situation is completely different today. Today, the umlauted vowel often carries an extremely emphatic stress while the subsequent vowel which originally must have triggered the umlaut is often unstressed and sometimes reduced to nothing. ${ }^{42}$ The umlaut is often accompanied by a lengthening of the umlauted vowel; hence umlaut cannot be accounted for in the context of vowel reduction. On the other hand, there are also cases where not the umlauted vowel, but the vowel of one of the subsequent syllables (which need not be the umlaut trigger), is stressed. For instance, in the phrase <yej $i$ yeza qurayli $>$ ['je·nz̆ 'je·zว̆ qư'râll I] 'let's create a new countryside', the umlauted vowels are both stressed and lengthened, while the umlaut trigger is extremely reduced (In yejza, the original umlaut trigger /i/ has been lowered to /a/. However, this change does not surface in the absence of a pause, see above). In the phrase <bir tösük éciliptu> [b̆r

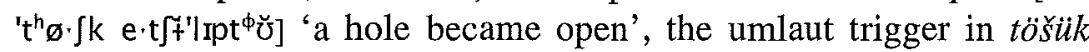
disappears completely, while the umlauted vowel both carries an emphatic stress and is lengthened. The umlauted vowel in the word éciliptu does not carry the main stress but is slightly lengthened. However, the stress does not rest on the umlaut trigger either, which is reduced, but on the syllable subsequent to the umlaut trigger. In so far as umlaut is productive today (that is, i-umlaut which involves an extant primary /i/), it appears to be a process completely detached from stress questions.

42 This is time and again even reflected in writing, e.g. in ertmaq [sic!] 'to wipe, to clean' (UTIL 6: 76) < T arït- (Clauson 1972: 207); cf. Uzb art-(ÖTIL 1: 55), Turkish artt-. Soviet Uyghur has yésmuq 'lentil' (Nadžip 1968: 797) < yasïmuq (Standard Uyghur of China: yessimuq). 
Besides the natural tendency of mutual interference of sounds, the predictable and in part obligatory umlaut patterns of Uyghur may possibly also be motivated by substratum influence of Eastern Middle Iranian, in which similar processes are encountered as well (SimsWilliams 1989: 168). ${ }^{43}$ Divergent stress patterns at earlier stages may (but need not) have contributed to the rise of umlaut in Uyghur as well.

As we have seen above, in front vowel words the sound process goes even further, as /e/ in open initial syllables is raised to /è/ even if there is no / $\mathrm{i}$ / in the subsequent syllable. This is probably in analogy to a genuine i-umlaut which was already firmly established in the language.

\section{Vowel lowering}

Contrary to umlaut, vowel lowering affects non-initial unstressed high syllables. At the first stage, the vowel is reduced. This reduction in terms of quantity is accompanied by an indifferent pronunciation in terms of quality. This stage is reflected for example in the Ili Salar word Goza 'lamb' < T quzi. This stage is comparable with the Uyghur vowel raising, which is also basically a reduction in quantity and quality (but of syllables with a low vowel). This stage of indifference (Indifferenzstufe, Johanson 1979: 70) can function as a starting point for a recategorization of the vowel with respect to certain phonetic features. This recategorization evolves in two steps. In Uyghur at least, maybe generally, the first step of recategorization concerns the opposition [ \pm open]. Originally high vowels are lowered. This is testified to by transitional unharmonic forms like Eastern Turki do 're 'medicine', mo:re 'chimney', hojle 'courtyard' and the Standard Uyghur word alte 'six'. In a second step the forms are harmonized according to the opposition [ \pm back], resulting in forms like dora, mora and hoyla as well as Yakut alta. Languages in which low vowels

43 However, Mongolic languages have $i$-umlaut as well. This is especially striking in Oirad (also spoken in Xinjiang), which has e.g. ädl 'equal' (Ramstedt 1935: 21; Todaeva 2001: 45) < adil, cf. Written Mongolian adali, and mörn 'horse' (Ramstedt 1935: 266; Todaeva 2001: 238) < morin. In Mongolic, a significant Iranian substratum does not seem probable. 
are subject to labial harmony may add the feature [+round] in a final step, e.g. Kirg tolo 'full' < tola < tolu. In Uyghur, the low vowels resulting from vowel lowering are raised again if the conditions for raising (see above) are fulfilled.

Hence, vowel lowering starts as a merely phonetic process of reduction of high unstressed vowels, which first bears no systematic implications. Only on a later stage, the vowel changes become systematicized. The result of vowel lowering may be phonologically relevant, as it can be seen from minimal pairs as Uyg qošuq 'spoon' vs. qošaq 'folk song'. However, in minimal pairs like this it is obviously not the opposition [ \pm high] which is phonologically signifcant, but the opposition [ \pm round], as the opposition [ \pm high] is neutralized in positions where the syllable becomes open and nonfinal (qošuqi 'his spoon' vs. qošiqi 'his folk song').

\section{Summary}

While vowel assimilations usually operate progressively in Turkic ("vowel harmony"), regressive vowel assimilations do occur as well. The Uyghur i-umlaut is especially famous and well-documented as it is a fully productive sound process and one of the most striking features of Uyghur phonology. Additionally, Uyghur has also u-umlaut which has received less attention in turcological literature, probably due to the fact that it is non-productive and affects selected lexical items only.

Both umlaut types also occur sporadically outside the Uyghur area as a non-productive phenomenon. While in the Turkish words yeşil 'green' and yeni 'new' the preceding /y-/ may have contributed to the change, Kazakh bäri 'all' and däri 'medicine' as well as Uzbek sekin 'slowly' are unambiguous instances of stray i-umlaut.

A few lexical items with u-umlaut have gained a comparatively broad distribution, as ötük 'boot', örük '*stone fruit' and various forms of * $\ddot{c} \breve{c k u}$ 'goat'. Even these however, have not reached very far to the west of the Turkic world.

Turkic umlaut phenomena do not seem to require the umlauted vowel to be unstressed.

Conversely, both vowel raising and vowel lowering result from 
the reduction of an unstressed vowel. While the Uyghur raising is a fully productive process which affects low vowels, vowel lowering obviously affects selected lexical or grammatical items only. Lowering in lexical items is much more spread across the Turkic world than the other sound processes mentioned in this contribution. Naturally, vowel lowering affects originally high vowels. Typical words displaying this process are keme 'ship', yigirme 'twenty' and yoyan 'huge, massive'. Reduction processes like these seem to have paved the way for the emergence of vowel harmony.

While both umlaut and vowel lowering do occur across the Turkic world, they are strikingly concentrated in the southeasternmost corner of the Turkic world, i.e. in Uyghur, the vowel system of which seems to have been especially vulnerable, and which obviously is especially innovative with respect to vowel changes.

\section{Abbreviations}

A

Alt

Azr

$\mathrm{Kaz}$

Krč

$\mathrm{Krg}$

$\mathrm{M}$

$\mathrm{P}$

SUyg

$\mathrm{T}$

Tkm

Tur

Tuv

Uyg

Uzb

Xak

Yak
Arabic

Altay Turkic

Azerbaidjani

Kazakh

Karachay-Balkar

Kirghiz

Mongolian

Persian

Standard Uyghur

Turkic

Turkmen

Turkish

Tuvan

Uyghur

Uzbek

Xakas

Yakut 


\section{References}

BAMRS: Boľ̌oj akademičeskij mongolsko-russkij slovar'. 4 Bde., Moscow 2001-2002.

Bammatov, Z.Z. 1969. Kumyksko-russkij slovar'. Moscow.

Baskakov, N.A. 1964. Russko-altajskij slovar'. Moscow.

- 1966. Dialekt černevyx tatar (Tuba-kiži). Grammatičeskij očerk $i$ slovar'. Moscow.

- 1967. Russko-karakalpakskij slovar'. Moscow.

- 1972. Dialekt kumandincev (Kumandy-kiži). Grammatičeskij očerk, teksty, perevody $i$ slovar'. Moscow.

Baskakov, N.A. and Inkižekova-Grekul 1953. Xakassko-russkij slovar'. Moscow.

Baskakov, N.A. and Toščakova, T.M. 1947. Ojrotsko-russkij slovar'. Moskow.

Bektaev, Kaldybaj 2001. Bol’̌̌oj kazaxsko-russkij russko-kazaxskij slovar'. Almaty.

Clauson, Gerard 1972. An Etymological Dictionary of Pre-ThirteenthCentury Turkish. Oxford.

Doerfer, Gerhard 1963-1975. Türkische und mongolische Elemente im Neupersischen. 4 vols., Wiesbaden.

Grønbech, Kaare 1942. Komanisches Wörterbuch. Türkischer Wortindex zum Codex Cumanicus. Kopenhagen.

Hahn, Reinhard F. 1991. Spoken Uyghur. Seattle-London: University of Washington Press.

Jarring, Gunnar 1933. Studien zu einer osttürkischen Lautlehre. Lund.

- 1964. An Eastern Turki-English dialect dictionary. Lund.

Johanson, Lars 1979. Die westoghusische Labialharmonie. Orientalia Suecana 27-28, 63-107.

- 1998. The history of Turkic. In: Johanson, Lars and Csató, Éva Á. (eds.). The Turkic Languages. London-New York: Routledge, 81-125.

Judaxin, K.K. 1965. Kirgizsko-russkij slovar'. Moscow [Reprint Biškek 1999].

Junker, Heinrich F.J. and Alavi, Bozorg 1965. Wörterbuch PersischDeutsch. Leipzig: Verlag Enzyklopädie.

Lessing, Ferdinand D. (ed.) 1960. Mongolian-English Dictionary. Berkeley-Los Angeles-London [Reprint Bloomington 1995]. 
Menges, Karl Heinrich 1959. Die aralo-kaspische Gruppe. In: Deny, Jean et al. (eds.). Philologiae Turcicae fundamenta 1. Aquis Mattiacis, 434-488.

Nadžip, E. N. 1968. Ujgursko-russkij slovar'. Uyyurče-rusče luyet. Moscow.

ÖTIL: Ozbek tilining izåhli luyati. 2 vols. Moscow 1981.

Pal'mbax, A. A. 1953. Russko-tuvinskij slovar'. Moscow.

Posch, Udo 1964. Khalkha und Verwandtes. In: Poppe, Nikolaus et al. Mongolistik. Handbuch der Orientalistik, Erste Abteilung, V.2, Leiden-Köln, 115-133.

Pritsak, Omeljan 1959a. Das Neuuigurische. In: Deny, Jean et al. (eds.). Philologiae Turcicae fundamenta 1. Aquis Mattiacis, 525563.

— 1959b. Das Altaitürkische. In: Deny, Jean et al. (eds.). Philologiae Turcicae fundamenta 1 . Aquis Mattiacis, 568-598.

- 1959c. Das Abakan- und Čulymtürkische und das Schorische. In: Deny, Jean et al. (eds.). Philologiae Turcicae fundamenta 1. Aquis Mattiacis, 598-640.

Ramstedt, G.J. 1935. Kalmückisches Wörterbuch. Helsinki.

Räsänen, Martti 1949. Materialien zur Lautgeschichte der türkischen Sprachen. Helsinki.

Redhouse Türkçe/Osmanlıca-İngilizce sözlük. Istanbul 1968.

Rešetov, V.V. and Šåabdurahmånov, Š. 1978. Ozbek dialektologiasi. Tåškent.

Sayim, Abduqeyyum 2007. Xoten xelq qošaqlirida učraydiran di'alekt terkibliri to $\gamma$ risida izdiniš. Til ve terǰime 2/2007, 11-13.

Sims-Williams, Nicholas. Eastern Middle Iranian. Schmitt, Rüdiger (Hrsg.). Compendium Linguarum Iranicarum. Wiesbaden 1989, $165-172$.

Slepcov, P.A. 1972. Jakutsko-russkij slovar'. Moscow.

Steingass, Francis 1892. A Comprehensive Persian-English Dictionary. London [Reprint: Delhi 2000].

TatRS: Tatarsko-russkij slovar'. Moscow 1966.

TDS: Türkmen dilinī sözlügi. Aš $\gamma$ abat 1962.

Tenišev, E.R. 1968. Tuvinsko-russkij slovar'. Moscow.

Tenišev, E.R. and Sujunčev, X.I. 1989. Karačaevo-balkarsko-russkij slovar'. Moscow. 
Thomsen, Kaare 1959. Das Kasantatarische und die westsibirischen Dialekte. In: Deny, Jean et al. (eds.). Philologiae Turcicae fundamenta 1. Aquis Mattiacis, 407-421.

Todaeva, B.X. 2001. Slovar' jazyka ojratov sin'czjana. Elista.

TRS: Raximi, M.V. and Uspenskaja, L.V. 1954. Tadžiksko-russkij slovar'. Moscow.

URS: Akobirov, S.F. and Mixajlov, G.N. 1988. Uzbeksko-russkij slovar'. Tashkent.

UTIL: Uyyur tilinin izahliq lugyiti. 6 vols., Beijing 1990-1999.

Vasmer, Max 1953-1958. Russisches etymologisches Wörterbuch. 3 vols. Heidelberg.

Vietze, Hans-Peter 1988. Wörterbuch Mongolisch-Deutsch. Leipzig.

Wehr, Hans 1985. Arabisches Wörterbuch für die Schriftsprache der Gegenwart. Arabisch-Deutsch. 5. Auflage, unter Mitwirkung von Lorenz Kropfitsch neu bearbeitet und erweitert. Wiesbaden: Harrassowitz.

Wurm, Stefan 1959. Das Özbekische. In: Deny et al. (eds.). Philologiae Turcicae fundamenta 1. Aquis Mattiacis, 489-563.

Yakup, Abdurishid 2002. An Ili Salar vocabulary. Introduction and a provisional Salar-English lexicon. Tokyo.

- 2005. The Turfan dialect of Uyghur. (Turcologica 63.) Wiesbaden.

Zenker, Julius Theodor 1866-1876. Türkisch-Arabisch-Persisches Handwörterbuch. 2 vols., Leipzig [Reprint: Hildesheim-ZürichNew York 1994]. 
